\title{
Front Matter: Volume 9979
}

, "Front Matter: Volume 9979," Proc. SPIE 9979, Laser Communication and Propagation through the Atmosphere and Oceans V, 997901 (8 November 2016); doi: 10.1117/12.2260741

EDent: SPIE Optical Engineering + Applications, 2016, San Diego, California, SPIE. United States 


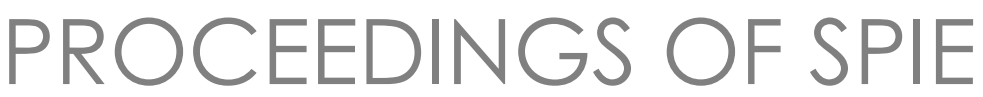

\title{
Laser Communication and Propagation through the Atmosphere and Oceans V
}

\author{
Alexander M. J. van Eijk \\ Christopher C. Davis \\ Stephen M. Hammel \\ Editors
}

30-31 August 2016

San Diego, California, United States

Sponsored and Published by

SPIE

Volume 9979 
The papers in this volume were part of the technical conference cited on the cover and title page. Papers were selected and subject to review by the editors and conference program committee. Some conference presentations may not be available for publication. Additional papers and presentation recordings may be available online in the SPIE Digital Library at SPIEDigitallibrary.org.

The papers reflect the work and thoughts of the authors and are published herein as submitted. The publisher is not responsible for the validity of the information or for any outcomes resulting from reliance thereon.

Please use the following format to cite material from these proceedings:

Author(s), "Title of Paper," in Laser Communication and Propagation through the Atmosphere and Oceans V, edited by Alexander M. J. van Eijk, Christopher C. Davis, Stephen M. Hammel, Proceedings of SPIE Vol. 9979 (SPIE, Bellingham, WA, 2016) Six-Digit Article CID Number.

ISSN: 0277-786X

ISSN: 1996-756X (electronic)

ISBN: 9781510603493

ISBN: 9781510603509 (electronic)

Published by

SPIE

P.O. Box 10, Bellingham, Washington 98227-0010 USA

Telephone +1 3606763290 (Pacific Time) · Fax +1 3606471445

SPIE.org

Copyright (C) 2016, Society of Photo-Optical Instrumentation Engineers.

Copying of material in this book for internal or personal use, or for the internal or personal use of specific clients, beyond the fair use provisions granted by the U.S. Copyright Law is authorized by SPIE subject to payment of copying fees. The Transactional Reporting Service base fee for this volume is $\$ 18.00$ per article (or portion thereof), which should be paid directly to the Copyright Clearance Center (CCC), 222 Rosewood Drive, Danvers, MA 01923. Payment may also be made electronically through CCC Online at copyright.com. Other copying for republication, resale, advertising or promotion, or any form of systematic or multiple reproduction of any material in this book is prohibited except with permission in writing from the publisher. The CCC fee code is 0277-786X/16/\$18.00.

Printed in the United States of America.

Publication of record for individual papers is online in the SPIE Digital Library.

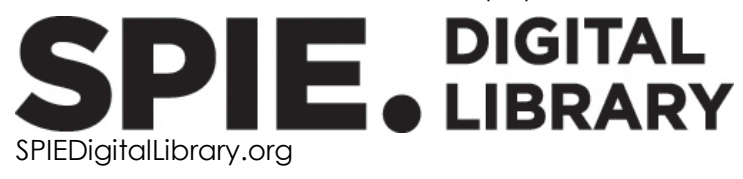

Paper Numbering: Proceedings of SPIE follow an e-First publication model, with papers published first online and then in print. Papers are published as they are submitted and meet publication criteria. A unique citation identifier (CID) number is assigned to each article at the time of the first publication. Utilization of CIDs allows articles to be fully citable as soon as they are published online, and connects the same identifier to all online, print, and electronic versions of the publication. SPIE uses a six-digit CID article numbering system in which:

- The first four digits correspond to the SPIE volume number.

- The last two digits indicate publication order within the volume using a Base 36 numbering system employing both numerals and letters. These two-number sets start with 00, 01, 02, 03, 04, $05,06,07,08,09,0 A, 0 B \ldots$.. 0Z, followed by 10-1Z, 20-2Z, etc.

The CID Number appears on each page of the manuscript. The complete citation is used on the first page, and an abbreviated version on subsequent pages. 


\title{
Contents
}

\author{
vii Authors \\ ix Conference Committee
}

\section{SESSION 1 COMPENSATION AND OPTIMIZATION}

997903 Optimization of beam geometry for focusing through turbulence [9979-2]

997904 Beaconless operation for optimal laser beam propagation through turbulent atmosphere [9979-3]

997905 Numerical validation of time-averaged, tilt-removed beam propagation in atmospheric turbulence by use of spatial filters [9979-4]

997906 Real-time characterization of the spatio-temporal dynamics of deformable mirrors [9979-5]

\section{SESSION 2 THEORY}

997907 Paraxial polarized waves in inhomogeneous media [9979-6]

997908 Vortex beam generation based on a fiber array combining and propagation through a turbulent atmosphere [9979-7]

997909 Empirical evaluation of the anisoplanatic bispectrum transfer function for extended objects [9979-8]

9979 OA Statistics and generation of non-Markov phase screens [9979-9]

\section{SESSION 3 FSO COMMS}

9979 OB Theoretical modeling of the MILES hit profiles in military weapon low-data rate simulators [9979-10]

9979 OC Laser radio: backhaul solution for 5G networks [9979-11]

9979 OD OptoRadio: a method of wireless communication using Orthogonal M-ary PSK (OMPSK) modulation [9979-12]

9979 OF Acemind new indoor full duplex optical wireless communication prototype [9979-14]

9979 OG Modified raised cosine waveform shaping with reduced peak to average power ratio [9979-15] 
$9979 \mathrm{OH}$ Study on polarization features of carbonaceous particles in atmosphere pollutants [9979-16]

\section{SESSION 4 PROPAGATION TO SPACE}

9979 Ol The adaptive optics and transmit system for NASA's Laser Communications Relay Demonstration project (Invited Paper) [9979-17]

9979 0J Laser remote maneuver of space debris at the Space Environment Research Centre [9979-18]

9979 OL Single detector stereo-SCIDAR for Mount Stromlo: data analysis [9979-20]

9979 OM Experimental analysis of adaptive optics compensation in free-space coherent laser communications [9979-21]

\section{SESSION 5 TURBULENCE EFFECTS AND MITIGATION}

997900 Implementation of a rapid correction algorithm for adaptive optics using a plenoptic sensor [9979-23]

\section{SESSION 6 TURBULENCE MODELS AND MEASUREMENTS}

9979 OP Simple method to measure effects of horizontal atmospherical turbulence at ground level [9979-24]

$99790 Q \quad$ The FESTER field trial [9979-25]

9979 OR The dependence of optical turbulence on thermal and mechanical forces over the sea [9979-26]

\section{SESSION 7 MODEL DEVELOPMENT I}

9979 OS Efficient physics-based predictive 3D image modeling and simulation of optical atmospheric refraction phenomena (Invited Paper) [9979-27]

9979 OT The influence of environmental parameters on dynamic infrared signatures [9979-28]

9979 OU EOSPEC: a complementary toolbox for MODTRAN calculations [9979-29]

\section{SESSION 8 MODEL DEVELOPMENT II}

9979 OV A model for predicting fog aerosol size distributions [9979-30] 


\section{SESSION 9 WAVEFRONT SENSING}

9979 0X Holographic wavefront sensor based on Karhunen-Loève decomposition [9979-32]

9979 OY Complex wavefront sensing with a plenoptic sensor [9979-33]

9979 OZ Imaging through water turbulence with a plenoptic sensor [9979-34]

\section{POSTER SESSION}

997914 Testing FSO WDM communication system in simulation software optiwave OptiSystem in different atmospheric environments [9979-39]

997915 Optical intensity scintillation in the simulated atmospherical environment [9979-40] 
Proc. of SPIE Vol. $9979997901-6$

Downloaded From: https://www.spiedigitallibrary.org/conference-proceedings-of-spie on 25 Apr 2023 Terms of Use: https://www.spiedigitallibrary.org/terms-of-use 


\section{Authors}

Numbers in the index correspond to the last two digits of the six-digit citation identifier (CID) article numbering system used in Proceedings of SPIE. The first four digits reflect the volume number. Base 36 numbering is employed for the last two digits and indicates the order of articles within the volume. Numbers start with 00, 01, 02, 03, 04, 05, 06, 07, 08, 09, 0A, 0B...0Z, followed by 10-1Z, 20-2Z, etc.

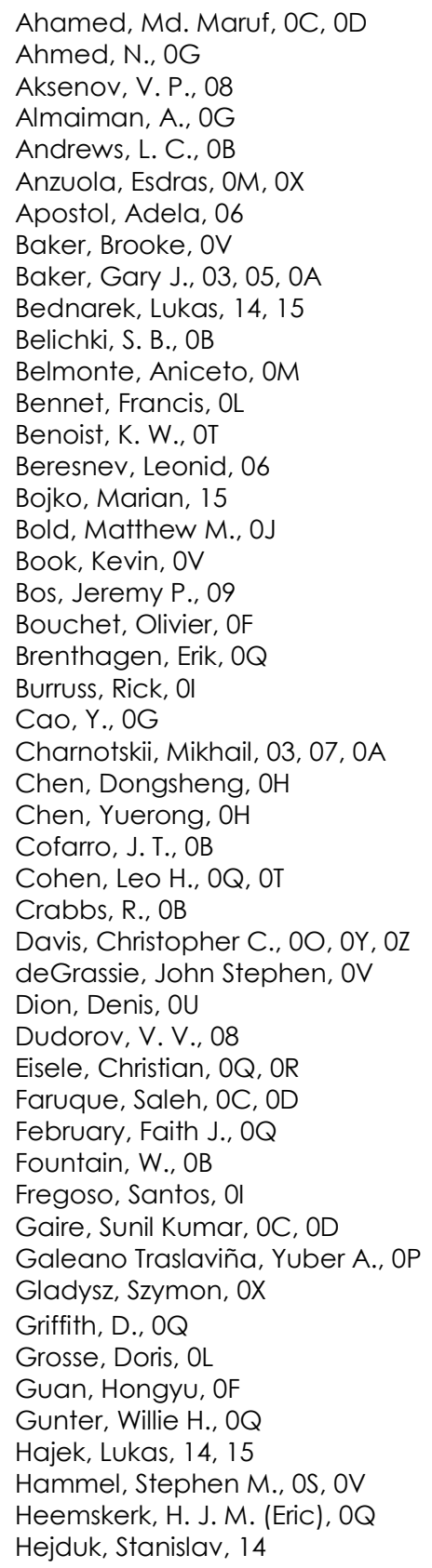

Herzog, Harrison, 01

Khizhnyak, Anatoliy, 04, 06

Kilpatrick, James, 06

Ko, Jonathan, OO, OY, OZ

Koago, Mokete S., OQ

Kolosov, V. V., 08

Korkiakoski, Visa, OL

Latal, Jan, 14, 15

$\mathrm{Li}, \mathrm{Da}, \mathrm{OH}$

$\mathrm{Ma}, \mathrm{Hui}, \mathrm{OH}$

Maritz, Benita, $0 Q$

Markov, Vladimir, 04, 06

Mhajerin-Ariaei, A., OG

Osborn, James, OL

Parrish, B. J., OB

Peet, B. J. A., OT

Perrufel, Micheline, OF

Phillips, R. L., OB

Piatrou, Piotr, OL

Piazzola, Sabino, ol

Reinhardt, Colin N., OS

Rigaut, Francois, $\mathrm{OL}$

Roberts, Jennifer E., Ol

Roberts, Lewis C., Jr., Ol

Rudiger, Joshua J., OV

Schulte, H., OQ

Seiffer, Dirk, OQ, OR

Shamee, B., OG

Smith, C. A., OB

Spiers, Gary D., Ol

Sprung, Detlev, OR

Stein, Karin, $\mathrm{OQ}, \mathrm{OR}, \mathrm{OX}$

Sternberg, A., $O Q$

Sucher, Erik, OQ, OR

Thomassen, Jan B., OQ

Thorn, Elliott, OL

Tijaro Rojas, Omar J., OP

Topsu, Suat, OF

Torres Moreno, Yezid, OP

Truong, Tuan N., Ol

Tsintikidis, Dimitris, OS

Tucker, F. M., OB

van Binsbergen, Sven A., OQ, OT

Vanderka, Aleš, 14, 15

van Eijk, Alexander M. J., OQ, OR

van lersel, Miranda, OQ, OT

van Rheenen, Arthur D., $0 Q$

van Riggelen, F., OT

Vasinek, Vladimir, 14, 15 
Veerman, H. E. T., OT

Vitasek, Jan, 14, 15

Vrahimis, George, $0 Q$

Wainman, Carl, $\mathrm{OQ}$

Wang, Yunfei, $\mathrm{OH}$

Wilkinson, S. R., OG

Willner, A. E., OG

Wu, Chensheng, 0O, OY, OZ

Zeng, Nan, $\mathrm{OH}$

Zepp, Andreas, OX

Ziyadi, M., OG

Proc. of SPIE Vol. $9979997901-8$

Downloaded From: https://www.spiedigitallibrary.org/conference-proceedings-of-spie on 25 Apr 2023 Terms of Use: https://www.spiedigitallibrary.org/terms-of-use 


\title{
Conference Committee
}

\author{
Program Track Chairs
}

Stephen M. Hammel, Space and Naval Warfare Systems Command (United States)

Alexander M. J. van Eijk, TNO Defence, Security and Safety

(Netherlands)

\section{Conference Chairs}

Alexander M. J. van Eijk, TNO Defence, Security and Safety (Netherlands)

Christopher C. Davis, University of Maryland, College Park (United States)

Stephen M. Hammel, Space and Naval Warfare Systems Command (United States)

\section{Conference Program Committee}

Larry C. Andrews, University of Central Florida (United States) Jaime Anguita, Universidad de Los Andes (Chile)

Shlomi Arnon, Ben-Gurion University of the Negev (Israel)

Sukanta Basu, North Carolina State University (United States)

Matthew M. Bold, Lockheed Martin Space Systems Company (United States)

Jeremy P. Bos, Michigan Technological University (United States)

Mikhail I. Charnotskii, MC Consulting (United States)

Gang Chen, University of California, Riverside (United States)

Robert J. Grasso, RJG Consulting (United States)

Jony Jiang Liu, U.S. Army Research Laboratory (United States)

Arun K. Majumdar, Naval Air Warfare Center Weapons Division (United States)

Vladimir B. Markov, Advanced Systems \& Technologies, Inc. (United States)

Dominic C. O'Brien, University of Oxford (United Kingdom)

Ronald L. Phillips, Florida Space Institute (United States)

William S. Rabinovich, U.S. Naval Research Laboratory (United States)

Karin Stein, Fraunhofer-Institut für Optronik, Systemtechnik und Bildauswertung (Germany)

Miranda van lersel, TNO Defence, Security and Safety (Netherlands)

Thomas Weyrauch, University of Dayton (United States)

Otakar Wilfert, Brno University of Technology (Czech Republic)

Heba Yuksel, Bogaziçi Üniversitesi (Turkey) 


\section{Session Chairs}

1 Compensation and Optimization

Stephen Hammel, SPAWAR Systems Center (United States)

Colin Reinhardt, SPAWAR Systems Center Pacific (United States)

2 Theory

Alexander M. J. van Eijk, TNO Defence, Security and Safety (Netherlands)

Mikhail I. Charnotskii, MC Consulting (United States)

3 FSO Comms

Christopher C. Davis, University of Maryland, College Park (United States)

Chensheng Wu, University of Maryland, College Park (United States)

4 Propagation to Space

Stephen Hammel, SPAWAR Systems Center (United States)

Colin Reinhardt, Space and Naval Warfare Systems Center Pacific (United States)

5 Turbulence Effects and Mitigation

Alexander M. J. van Eijk, TNO Defence, Security and Safety

(Netherlands)

Stephen Hammel, SPAWAR Systems Center (United States)

6 Turbulence Models and Measurements

Christopher C. Davis, University of Maryland, College Park

(United States)

Matthew Bold, Lockheed Martin Space Systems Company

(United States)

7 Model Development I

Stephen Hammel, SPAWAR Systems Center (United States)

Jeremy P. Bos, Michigan Technological University (United States)

8 Model Development II

Christopher C. Davis, University of Maryland, College Park (United States)

Miranda van lersel, TNO Defence, Security and Safety (Netherlands)

9 Wavefront Sensing

Alexander M. J. van Eijk, TNO Defence, Security and Safety

(Netherlands)

Miranda van lersel, TNO Defence, Security and Safety (Netherlands) 